\title{
Professional Practice as an Element of Taxonomy - A Case of IT Students at the Polytechnic of Rijeka
}

\author{
doi:10.3991/ijet.v5s2.1248 \\ Miro Frančić, Ivan Pogarčić, Maja Gligora Marković \\ Polytechnic of Rijeka, Rijeka, Croatia
}

\begin{abstract}
There are two reasons for a formal review of the formal forms of education: the development speed of datacommunication technologies and the increasing willingness of business entities to apply the same in a very strong competitive battle for dominance at the market. Although not only reason they are a sufficient challenge for educational institutions to adjust their curricula especially when they will help to better prepare their students for the labour market. Professional practice as a form of the highest levels of taxonomies, observed by Bloom's scale, should be used for evaluating student performance, but also for evaluating the quality and marketing of all available programs. This paper presents the experience of professional studies of computer science at Polytechnic of Rijeka acquired through the organization of professional practice in those businesses, which represent a potential place of work after the completion of studies. Conducted research, together with the acquired experience can be a framework for any changes or modifications to curriculum and teaching methods. Respondents pattern for the two main groups: business owners, which basic business is providing IT services and those which use computer to support base of operations. What do respondents who supervise professional practice think about the readiness of graduates for inclusion in their business, which competencies are expected of potential candidates for employment and what are their proposals for changing the program?
\end{abstract}

Index Terms-professional practice, levels of taxonomy, curriculum and teaching methods, competencies

\section{INTRODUCTION}

Development of science, progress in technology and technological solutions change all human activities. The speed of changing and improving technological solutions put in front of every business system a problem of fast and efficient adjustment of employees to the mentioned innovations. Development and implementation of information technologies require that all human activities make certain modifications both in form and content. Globalisation in business can be observed as consequence of ICT implementation and possibility of fast and efficient exchange of information required for business transactions. This consequently demands efficient and complete training of employees which results in knowledge, skills and capabilities respectively competencies - an expression frequently met in recent literature linked to these issues. Authors believe that knowledge or skill. All the above mentioned does not bypass education as function since education itself is a way of gaining knowledge and skills. From that point of view there is an urge for constant adjustment of schools and educational institutions as specific forms of business systems. This paper is trying to recognize and define the most important causes of changes which recently have been occurring in education, to check whether the existing mechanisms of grading the realised knowledge are satisfying and to propose specific activities that can lead to appropriate aimed consequences. What are the consequences of reform caused by accepting the Bologna Declaration and how to avoid negative consequences especially the ones that tend to become trends. For this purpose a research has been conducted within obligatory professional practice on vocational and specialist Study of computer science at Polytechnic of Rijeka. Research has involved business subjects whose primary activity is providing the information services but also those who use these same services. Authors purposely exclude definition of "information services" due to wideness it covers starting from simple services to applicative solutions required for specific forms of guiding the business.

\section{STATE OF THE ART AND SO ON}

\section{A. Bologna Declaration as political frame?}

Integration of Europe refers to integration of all areas, including the education as well. Concerning the education, the idea of integrating that field is best described in the first state of Sorbonne Joint Declaration: „Relevant as they are, they should not make one forget that Europe is not only that of the Euro, of the banks and the economy: it must be a Europe of knowledge as well. Authors must strengthen and build upon the intellectual, cultural, social and technical dimensions of our continent.[1] Sorbonne Joint Declaration was preceded by the Lisbon Recognition Convention that agreed the equal rights to education respectively: "No discrimination shall be made in this respect on any ground such as the applicant's gender, race, colour, disability, language, religion, political opinion, national, ethnic or social origin" [2]. Other conclusions of Council of Europe/UNESCO Convention are recommendations to states that have ratified the above mentioned conventions in terms of their realisations. After accepting these two documents, Europe will accept central document of Bologna Declaration which will set mutual frames in European higher education. The main goal is to introduce and accept common terminology and common standards respectively "adoption of a system of easily readable and comparable degrees". The second goal is of organisa- 
tional and operation character and it assumes acceptance of so-called Anglo-Saxony model 3-5-8 or 3 (bachelor) + 2 (master) +3 (doctor) during the higher education process. By ratification of this Declaration each country signatory modified its higher education system into a form that would provide equal system of scoring (ECST scores) the final success. ECTS scores are presumption of students' mobility within European area. All these would ensure European dimension and European quality of higher education. [3] The mentioned three documents will be introduced in the same time intervals of two years after the Salamanca Convention and Göteborg Deklaration and Prague Comunique of Ministers (2001), Graz Declaration of the European University Association and The Berlin Comunique of Ministers, (2003) and the Bergen communiqué (2005), London Communiqué (2007). All the above mentioned documents are known as «Magna charta universitatum». The Bologna 6th Ministerial Conference will take place in Leuven/Louvain-la-Neuve in Belgium on 2829 April 2009.

Among other mentioned documents authors should put emphasis on "Europe's Universities beyond 2010: Diversity with a Common Purpose" that represents formal conclusions of Council of the EUA on 13 April 2007 respectively London Communiqué (2007). The content of document in several chapters defines propositions of the most important activities and goals established on experiences of implementing the former prepositions and decisions for realising the vision of Strong Universities for Europe after 2010. Shortly: the goal of Strong Universities for Europe that will ensure the Knowledge Society, realise a diversified university system, provide the fundamental importance of university autonomy and connect Universities and an inclusive society.

Named aims should be realised through:

1. Building the European higher education area: refocusing on key goals, A stronger student focus, ECTS and further ECVET, Creating a supportive learning environment, Employability, Lifelong Learning,

2. The internationalisation of the European higher education area: Internationalisation and the "Bologna Trademark", Institutional strategies for internationalisation and Further developing internationalisation,

3. Promoting research and innovation: Linking higher education and research, Embedding high quality doctoral programmes in universities, Developing institutional strategies for research, Promoting innovation capacity, University-enterprise collaboration, Cost accounting of research activities, More flexible legal and regulatory conditions and Open Access,

4. Quality: Quality processes and institutional mission, The link to external accountability, The European dimension of quality,

5. Autonomy and funding: Institutional autonomy of Universities, Increasing and diversifying funding streams and Private contributions to higher education.[4]

The above mentioned facts represent political frame of action. Concretisation and operational performance is left to local areas - states. Dynamics and form of implementation are indirectly defined through possibilities of a concrete environment. The attention should be given to mode of adjusting the environmental specificities. However, the process of building the European higher education area lasts more then ten years in most of European countries within and outside the EU.

\section{B. Bologna Declaration in concrete Croatian environment?}

What are the specific circumstances in Republic of Croatia within which the grounds of mentioned declarations and conventions are being implemented? Croatian higher education system and system of polytechnics respectively scientific, vocational and higher-education studies which grounds and functioning is being based upon official legal act. [5]. However, the mentioned Law does regulate formal-legal functioning of mentioned institutions. The other legal acts regulate educational contents and forms and modes of their realisation. Educational contents, plans and their realisation are under control of authorised Ministry. Defined conditions of autonomy and funding are mostly harmonised with concrete circumstances. Trend of increasing the private higher education schools should also be mentioned. Balance between plans and programme is prerequisite of horizontal and vertical progress of students along with full transparency of credit system. Transition from university pillar to polytechnic or vice versa is not clearly defined and waits the operational performance of credit system for vocational education and training (ECVET) scoring system within frames of vocational education or education for professions.

Structuring the education into two or three-semester cycle is autonomous right of individual institution (university, faculty, polytechnic) and it is harmonised with its possibilities. Relationship between higher education institution and its environment greatly determine quality of its functioning. The assumption is that environment of higher education institution should provide: a supportive learning environment, employability, Lifelong Learning.

\section{Use case: Vocational study of Information Science at Polytechnic of Rijeka in general}

Mission of Polytechnic of Rijeka is higher education for entrepreneurial and creative cadre required in market economy and globalisation processes, who will be able to qualitatively apply gained professional knowledge in practice. The main assignment of Polytechnic is to educate professionals who are more oriented towards practice and individual application of professional knowledge and scientific methods specific for individual educational area that is from the beginning directed towards future profession.[6]

Vocational study of Information Science and Vocational specialist study of Information science at Polytechnic of Rijeka are organised according to scheme 3-2-(3) with still unidentified third level at this vertical of binary educational system. Polytechnic of Rijeka is state institution and structurally it represents a part of formal higher education system. Studies do have allowances for their realisation and they ought to be renewed every five years on basis of evaluation made by body of authorised Ministry. Study programs are defined during the establishment of Polytechnic but they can be partially modified. More detailed modification requires renewal of allowance document. Organized programs are harmonised through their content, heaviness and their credit values with programs of similar institutions in Europe. Their basic assignment puts emphasis on orientation towards profession and fastest possible inclusion into the labour market. Study of 
Information science on both levels should enable students for work places and assignments in which they will prove their knowledge, skills and high level of competence in realisation of confined tasks. Gained knowledge and skills are basic ground for development of competences in mentioned affairs.

Knowledge acquired after finishing individual level of Information science, Bachelor of Information science or Professional specialist of Information science, through their title do not precise real abilities of student who ended their study. On the other hand, recent literature from the USA defines information science expert as broader term that includes a variety of specialities in the field. According to [7] it would include business that encompass telecommunications, broadcasting, publishing, software, internet service providers, web search portals, data processing services etc. Narrower specialities such as Computer system analysts, Computer hardware engineers, Data base or network administrator refer to computers. Since information science is in certain manner service science, specific circumstances such as Government or administration (in criminal research) demand better differentiation in specialisation [8].

Learning at each study level finishes with semester professional practice which students realise in a concrete business environment. This puts them in situation where they are able to prove how much they are capable of applying their knowledge and skills and their readiness to be included in business processes.

\section{Use case: Vocational study of Information science at Polytechnic of Rijeka - where are the obstacles?}

Reform of higher education in compliance with postulates of Bologna Declaration significantly influenced the educational process. Changes are noticeable in creation of curriculum, performance, tracking and valorisation of achieved success by students. Constant monitor of students and semester shape of curriculum change former practice in great measure. It is natural that changes in systems such as higher education will become more inactive. Scoring the activities and forming the final grade upon total number of collected scores should be replacement for former modes of monitoring and grading. Final aim of declaration: stronger students require, among others, redefining of appropriate forms of evaluating their success.

Second important reason for mentioned redefinitions is a possibility of applying different forms of e-Learning. eLearning excludes time and location dependency of realisation which gives the students an opportunity for more efficient and free organisation of time and location required for learning.

Speed of developing and improving information technologies requires additional forms of vocational training on Study of information science. The best way to train students for quick adjustment to business for which they are being educated is their inclusion in organised professional semester practice in business systems that make Polytechnic's environment. Need for cooperation with these systems is necessary through cooperation organised by Polytechnic or through contacts and cooperation initiated by students themselves. Interest should be mutual since it helps to achieve full awareness of both future employers and future employees. Semester of activities is period long enough to define and evaluate abilities of future employees.

Problems are more immanent in organisation of semester practice. One group of problems is connected to business systems in which the practice can be performed and is conditioned by general situation in institutions and business systems. The general condition of business system is reflection of broader situation and relationships in its business performance and financial possibilities. Semester professional practice for students of Information science can be organised at all positions that demand information backup for business. Therefore, duly profiling of students and their connecting with business systems of environment should be executed before giving the actual order to realise assignments.

Additional problem is the frequent lack of pedagogical, didactic-method and psychological education of teachers in higher education institutions due to fact that education is primary and nurturing component of higher education institution is secondary.

\section{E. Use case: Vocational study of Information science at Polytechnic of Rijeka - student as a product?}

Experience in organisation and realisation of semester professional and specialist practice has implied the following:

1. Educational program of study should be more often harmonised and it should have more space for modifications.

2. Harmonisation of programs should necessarily follow the ICT achievements.

3. Different forms of student activities organised through e-Learning will require modification of classic taxonomy. [9]

4. Feedback information that can be collected from realised professional practice and complete communication with business systems in which the practice is being realised make basis for efficient modifications.

5. Professional practice should be organised in such manner that it can be efficiently implemented into applicable taxonomy of grading and evaluating student's complete achievement.

In compliance with experiences obtained in organisation of semester professional practice and specialist practice authors will obtain results of the researches.

\section{SURVEY AND RESEARCH}

\section{A. Survey content}

With aim of collecting the relevant information connected with research subject, survey was compiled of four groups of questions. The first group refers to general information about business subject. Questions that relate to activity enabled the grouping of examinees in two aimed clusters: the ones who provide information services as basic function and the others who use information science as backup of core business. From these groups of questions authors should abstract the question of number of employees who ended study of information science at Polytechnic of Rijeka and question of representation of individual professions in information businesses. The second group of questions was created for receiving the information of how much do business subject know content 
of information science expert's education and what presents the lack of present contents according to them. The third group of questions is related to collecting the info about inclusion of business subjects in educational system, especially at Polytechnic of Rijeka. The fourth group of questions is basis for improving the educational system. The examinees should represent their views about expected results when it comes to information science expert's education.

\section{B. Analysis and interpretation of collected data}

Surveys have been mailed to 80 persons who were in last period mentors to students of Polytechnic during the realisation of their semester professional practice. Totally 39 examinees answered, 31 of them to all questions and 8 partially. Only complete surveys have been processed. Statistical analysis of collected data was completed with aim of providing the answers to the following questions:

1. Representation of individual professions in information business.

2. Representation of Information science graduates of Polytechnic of Rijeka in business systems.

3. Awareness of educational contents at Study of information sciences at Polytechnic of Rijeka

4. Cooperation between educational institutions and business subjects

5. Expectations of information education.

Additionally, the aim was to compare research results for companies which basic business is providing information services with those which use information as backup of their core business. On grounds of answers provided for the first question about core business of companies all the answers were divided into two groups. The first group (G1) constitutes answers of companies which core business is providing the information services, and the other (G2) answers of companies which do not use information as core business. Out of 31 totally analysed surveys, 18 belong to the first group and 13 to the second.

Table I implies that in both groups information science graduates are the most represented in information business, then information science professors while economists are most represented in companies of the second group. More companies from the second group use outsourcing or the combination of own development and outsourcing so these companies employ less information science experts. It is interesting that companies which provide information services for development of their information system use outsourcing or combined approach. Notable is also the number of information science experts who graduated information sciences at Polytechnic of Rijeka and are employees of analysed companies.

TABLE I.

RANKING ACCORDING TO REPRESENTATION OF INDIVIDUAL PROFESSIONS AT INFORMATION ASSIGNMENTS

\begin{tabular}{|l|c|c|c|c|c|c|c|c|c|c|}
\hline & \multicolumn{5}{|c|}{ Group 1 } & \multicolumn{5}{|c|}{ Group 2 } \\
\hline Criterion Rank & $\mathbf{1}$ & $\mathbf{2}$ & $\mathbf{3}$ & $\mathbf{4}$ & $\mathbf{5}$ & $\mathbf{1}$ & $\mathbf{2}$ & $\mathbf{3}$ & $\mathbf{4}$ & $\mathbf{5}$ \\
\hline Information science experts & 5 & 2 & & 1 & & 6 & 7 & 1 & 1 & \\
\hline Electro-engineer & 4 & 2 & 1 & 2 & & 3 & 1 & 1 & 3 & 1 \\
\hline Economists & 1 & 1 & & 3 & 1 & 3 & 1 & 6 & 1 & \\
\hline Mathematic professors & & 2 & 3 & 1 & & 3 & 5 & 1 & 0 & 1 \\
\hline The others & 3 & 2 & 3 & & 3 & 3 & 3 & 3 & 2 & 3 \\
\hline
\end{tabular}

TABLE II.

PROFILE OF COMPANIES

\begin{tabular}{|c|c|c|c|c|c|}
\hline \multirow{2}{*}{$\begin{array}{c}\text { Number of } \\
\text { employees }\end{array}$} & \multicolumn{2}{|c|}{$\begin{array}{c}\text { Number of } \\
\text { answers }\end{array}$} & $\begin{array}{c}\text { Number of "informa- } \\
\text { tion science experts" }\end{array}$ & \multicolumn{2}{|c|}{$\begin{array}{c}\text { Number of } \\
\text { answers }\end{array}$} \\
\cline { 2 - 6 } & $\mathrm{G} 1$ & $\mathrm{G} 2$ & & $\mathrm{G} \mathrm{1}$ & $\mathrm{G} \mathrm{2}$ \\
\hline 1 & 1 & 0 & 1 & 1 & 3 \\
\hline $2-5$ & 4 & 3 & $2-5$ & 8 & 7 \\
\hline $6-20$ & 7 & 3 & $6-10$ & 1 & 0 \\
\hline $21-100$ & 5 & 1 & $11-20$ & 4 & 1 \\
\hline$>100$ & 1 & 6 & $>20$ & 4 & 2 \\
\hline
\end{tabular}

TABLE III.

PROFILE OF POLYTECHNIC

\begin{tabular}{|c|c|c|c|c|c|}
\hline $\begin{array}{c}\text { Number of "in- } \\
\text { formation sci- } \\
\text { ence experts" } \\
\text { from Polytechnic }\end{array}$ & \multicolumn{2}{|c|}{$\begin{array}{c}\text { Number of } \\
\text { answers }\end{array}$} & \multirow{2}{*}{$\begin{array}{c}\text { Development } \\
\text { mode of IS }\end{array}$} & \multicolumn{2}{|c|}{$\begin{array}{c}\text { Number of } \\
\text { answers }\end{array}$} \\
\cline { 2 - 3 } \cline { 5 - 6 } & G 2 & G 1 & G 2 \\
\hline 0 & 7 & 6 & own development & 14 & 3 \\
\hline 1 & 4 & 3 & outsourcing & 1 & 2 \\
\hline 2 & 6 & 1 & combination & 4 & 8 \\
\hline 3 & 1 & 0 & & & \\
\hline$>3$ & 0 & 3 & & & \\
\hline
\end{tabular}

Collected answers for both groups of examinees imply they are extremely bad introduced with educational contents of their potential employees.

TABLE IV

KNOWLEDGE OF EDUCATIONAL CONTENTS AT POLYTECHNIC

\begin{tabular}{|c|c|c|}
\hline \multirow{2}{*}{$\begin{array}{c}\text { Knowledge of educational con- } \\
\text { tents at Polytechnic }\end{array}$} & \multicolumn{2}{|c|}{ Number of answers } \\
\cline { 2 - 3 } & Group 1 & Group 2 \\
\hline not at all & 10 & 5 \\
\hline partially & 6 & 7 \\
\hline completely & 2 & 1 \\
\hline
\end{tabular}

TABLE V.

INCLUSION IN EDUCATION AT POLYTECHNIC

\begin{tabular}{|c|c|c|c|c|c|}
\hline \multirow{2}{*}{$\begin{array}{l}\text { Engagement in } \\
\text { lecturing at } \\
\text { Polytechnic of } \\
\text { Rijeka }\end{array}$} & \multicolumn{2}{|c|}{$\begin{array}{c}\text { Number of } \\
\text { answers }\end{array}$} & \multirow{2}{*}{$\begin{array}{l}\text { Participation in } \\
\text { creation of } \\
\text { curriculum }\end{array}$} & \multicolumn{2}{|c|}{$\begin{array}{c}\text { Number of } \\
\text { answers }\end{array}$} \\
\hline & G 1 & G 2 & & G 1 & G 2 \\
\hline yes & 1 & 0 & yes & 5 & 2 \\
\hline no & 17 & 13 & no & 13 & 11 \\
\hline $\begin{array}{l}\text { Need for inclu- } \\
\text { sion of experts }\end{array}$ & \multicolumn{2}{|c|}{$\begin{array}{l}\text { Number of } \\
\text { answers }\end{array}$} & \multirow{2}{*}{$\begin{array}{l}\text { Willingness to } \\
\text { change educa- } \\
\text { tional system }\end{array}$} & \multicolumn{2}{|c|}{$\begin{array}{c}\text { Number of } \\
\text { answers }\end{array}$} \\
\hline $\begin{array}{c}\text { in practical } \\
\text { work into edu- } \\
\text { cational system }\end{array}$ & G 1 & G 2 & & G 1 & G 2 \\
\hline yes & 18 & 13 & yes & 2 & 1 \\
\hline no & 0 & 0 & no & 6 & 6 \\
\hline
\end{tabular}

TABLE VI

RANKING OF COMPETENCES

\begin{tabular}{|c|c|c|c|c|c|c|c|c|c|c|c|c|c|}
\hline & \multicolumn{7}{|c|}{ Group 1} & \multicolumn{6}{|c|}{ Group 2} \\
\hline Rank & 1 & & & & & & & & 2 & & 5 & & 8 \\
\hline Innovativeness & \begin{tabular}{|l|}
3 \\
\end{tabular} & 2 & & 2 & 2 & 2 & & 2 & 1 & 3 & 1 & & 3 \\
\hline & & 3 : & & 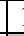 & 2 & 5 & 1 & 3 & & 2 & & & 3 \\
\hline $\begin{array}{r}\text { Ruling th } \\
\mathrm{g}\end{array}$ & 3 & 2 & & & & & & & 1 & 2 & & & 3 \\
\hline & & $1[2$ & & & 18 & & 4 & & $3 \sqrt[3]{3}$ & & & \begin{tabular}{ll|l}
2 & 1 \\
\end{tabular} & 1 \\
\hline $\begin{array}{r}\text { Modelling o } \\
\mathrm{e}\end{array}$ & & $3 \mid$ & & & & 3 & 2 & & 4 & & 3 & & 1 \\
\hline Usage of spe & & & & & 5 & & 7 & & & & 3 & & 2 \\
\hline & 11 & $3[2$ & & & & & & & \begin{tabular}{l|l}
2 & 1 \\
\end{tabular} & 12 & 2 & 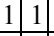 & \\
\hline Willingness for teamwork & & & & & & & & & & & & & \\
\hline
\end{tabular}


Table implies there is insufficient representation of people who work in practice in realisation of education but certain number of them has participated in creation of curriculum. There is no doubt about a necessity to include professionals from practice into the educational system

According to collected answers, capability of analytical thinking and affinity for team work are the most important competencies for both groups. The both groups have similar expectations in respect of innovations. Noninformation companies give advantage to project management and modelling of business processes. Ruling the program languages is a competence more expected by information companies but not highly ranked. This ranking is in compliance with dedication which examinees give to study programs in relation to industrial certificates notable in Table VII.

TABLE VII ADVANTAGE BY EMPLOYING

\begin{tabular}{|c|c|c|}
\hline \multirow{2}{*}{ Advantage in employment } & \multicolumn{2}{|c|}{ Number of answers } \\
\cline { 2 - 3 } & Group 1 & Group 2 \\
\hline Study education & 11 & 10 \\
\hline Industrial certificates & 7 & 3 \\
\hline
\end{tabular}

\section{WHAT NEXT}

Conducted research represents beginning of more detailed research that should be broaden to other higher education institutions as well, firstly to the area of Primorskogoranska county and its neighbouring counties and then to the rest of Republic of Croatia. Research should be broadening from the aspect of examinees as well. Besides companies, research should encompass the graduates as well in order to collect feedback data about how much did the educational system help them to gain competence for inclusion into working processes. In order to animate this research, research results should be used as grounds for improving the curriculum, introducing changes into educational performance and tighter connections with business subjects.

\section{CONCLUSION}

Research results have confirmed ex-ante hypotheses that are result of experiences gained through several years of organising the professional practice. Starting from a fact that semester professional practice should express willingness of students to perform future assignments, their capabilities, achieved knowledge and proof of their competence in specific place authors have conducted survey through which authors have concluded:

1. Necessity for inclusion of business systems, the future working places of Polytechnic's students, into creation of curriculum and importance of considering their opinions.

2. Need for more complete evaluation of relationship Business system - Polytechnic - student in all directions by lines of described triangle.
3. Exploitation of professional practice as ground for higher degrees of Blooms taxonomy in monitoring and evaluating students respectively evaluation of their capability to analyse within frames of assigned tasks, capability of synthesizing the learned, making conclusions and capability of objective evaluation.[10]

Although the basic hypotheses in research are not the only ones that can be stated as starting point, the mutual aim is to present how reform in higher education is not merely reform of institutions but instead it opens the possibilities which should ensure more qualitative education and product of education - highly professional information science expert whose knowledge and skills will make him competent for assignments that will be put in front of him after finishing his studies.

\section{REFERENCES}

[1] www.bologna.msmt.cz/PragueSummit/Sorbonnska\%20deklaraceplne\%20zneni\%20aj.doc

[2] http://www.coe.int/t/dg4/highereducation/Recognition/LRC_en.as p

[3] www.bologna-bergen2005.no/Docs/00Main_doc/990719BOLOGNA_DECLARATION.PDF

[4] Lisbon declaration: "Europe's Universities beyond 2010: Diversity with a Common Purpose" European University Association asbl, Rue d'Egmont 13, 1000 Brussels, Belgium, ISBN: 9789078997030

[5] Law of higher education institutions, National journal, No. 54/96, Zagreb

[6] http://www.veleri.hr/pages/veleuE8ili9Ate/ danas.php

[7] M. Farr,: Top 100 Computer and Technical Careers, JIST Publishing inc., Indianopolis, 2007

[8] Corporate\&Government United States: Information technology jobs in America, Info Tech Employment Publication, New York, 2007, 2008

[9] I.Pogarčić and J.Vujić Žiljak: eLearning: Is time for eTaxonomy?, EDU' 07) WSEAS Press, 2007. Venice, Italy 145-152

[10] B. S. Bloom: Taxonomy of Educational Objectives, Handbook I: The Cognitive Domain. New York: David McKay Co Inc 1956.

\section{AUTHORS}

Frančić Miro, lecturer is with the Polytechnic of Rijeka,Business Department, Study of Computer Science, Rijeka, Croatia (e-mail: mfrancic@veleri.hr)

Pogarčić Ivan,senior lecturer is with the Polytechnic of Rijeka,Business Department, Study of Computer Science, Rijeka, Croatia (e-mail: pogarcic@veleri.hr)

Gligora Marković Maja, lecturer is with the Polytechnic of Rijeka,Business Department, Study of Computer Science, Rijeka, Croatia (e-mail: mgligoram@veleri.hr)

This article was modified from a presentation at The 32nd International Convention MIPRO on information and communication technology, electronics and microelectronics., in 25-29 May 2009, Opatija, Croatia. Manuscript received, 20 February 2010. Published as resubmitted by the authors 1st March 2010 